\title{
PROFILE OF ORGANIC FOOD CONSUMERS
}

\author{
Mirjana Kranjac 1 , Jelena Vapa-Tankosic ${ }^{2}$, Milena Kneževic ${ }^{3}$
}

\begin{abstract}
Summary
The aim of this study is to prove that profile of organic food consumers is dependent on their socio-demographic characteristics as well as to shape universal organic food consumer profile. The survey included 398 consumers in Serbia. Results indicate existence of typical consumer's profile. The findings could be generalized proving that socio-demographic profiles in a larger population are strictly related to the decision to utilize organic food. The study finally contributes to the stakeholders in general, since the knowledge of the attributes can help all of them to play more active role in this supply chain. It should stimulate the personalized approach to the particular groups of consumers based on sociodemographic characteristics in order to intensify consumption of organic food and to create different marketing plans dependent on the particular countries or areas.
\end{abstract}

Key words: organic food, consumer profile, socio-demographic characteristics, supply chain.

JEL: E21, D12, Q13.

\section{Introduction}

Organic has become a way of living. The organic sector in the EU has been rapidly developing during the past decades. According to Eurostat data, the EU-28 had in 2015 a total area of 11.1 million hectares cultivated as organic. During the last decade, organic area in the EU increased by about 500000 hectares per year. The whole organic area represents only $6.2 \%$ of total utilized agricultural area in Europe. The organic area is cultivated by almost 185 000 farms across Europe. Around 306500 organic operators (producers, processors and importers) were registered in the EU-28 in 2015. Most of the organic land (78\%) and of organic farms (81\%) are situated in the EU Member States having joined the EU before 2004 (the so called EU-15), in which national and European legislation stimulated the development

1 Mirjana Kranjac Ph.D., Associate Professor, University Novi Sad, Faculty of Technical Sciences, Dositeja Obradovića Square no. 6, 21000 Novi Sad, Serbia, Phone: +381 62633 590, E-mail: mirjana.kranjac@uns.ac.rs.

2 Jelena Vapa-Tankosić Ph.D., Associate Professor, University Business Academy, Serbia, Cvećarska Street no. 2, 21000 Novi Sad, Serbia Phone: +381 63460 585, E-mail: jelena.vapa@fimek.edu.rs

3 Milena Knežević Ph.D., University of Defence in Belgrade, Serbia, Pavla Jurišića Šturma Street no. 1, 11000 Belgrade, Serbia, E-mail: milena.knezevic@mod.gov.rs

EP 2017 (64) 2 (497-514) 
of this sector. The New member States which are lagging behind in almost all aspects of development of the "old" EU member states, has represented an additional challenge to the makers of the EU agricultural policy (Vapa-Tankosić, Stojsavljević, 2014).

The European countries having joined the EU since 2004 are quickly expanding the organic sector as well. They registered a 12\% yearly growth rate in their organic area for from 2002 to 2015. Statistical information on organic agriculture is now available in 172 countries (DG Agriculture and Rural Development, Unit Economic Analysis of EU Agriculture, 2016).

In 2014, the European organic market grew by approximately 7.6 percent and has reached value of more than 26 billion euros. Consumers in the European Union spent 23.9 billion euros on organic food. This is shown by the latest data provided by the Research Institute of Organic Agriculture (FiBL) and the Agricultural Market Information Company (AMI) in association with IFOAM EU. Germany is the biggest organic market in Europe with a share of $30 \%$ of retail sales. It is followed by France (18\%), the United Kingdom (9\%) and Italy (8\%) (Heinze, 2016).

Definition of organic food provided by the USDA National Organic Program (NOP) is as follows:"Organic food is produced by farmers who emphasize the use of renewable resources and the conservation of soil and water to enhance environmental quality for future generations. Organic meat, poultry, eggs, and dairy products come from animals that are given no antibiotics or growth hormones. Organic food is produced without using most conventional pesticides; fertilizers made with synthetic ingredients or sewage sludge; bioengineering; or ionizing radiation. Before a product can be labeled "organic," a Government-approved certifier inspects the farm where the food is grown to make sure the farmer is following all the rules necessary to meet USDA organic standards. Companies that handle or process organic food before it gets to your local supermarket or restaurant must be certified, too." (What does organic mean?, 2016). In the present when agricultural production are dying out due to diseases and weaknesses, poisoning, pesticides, climate changes and presence of extreme temperatures, droughts and floods, transfer to organic production secures the highest quality and absolute health safety with protection of the environment (Simeunović , 2016).

As organic food is being more popular there is increasing demand for academic research on profile, habits and attitudes of consumers towards organic food (Shepherd et al., 2005). Structure of consumers and their behavior considered to be essential which have to be studied in sectors such as economy, marketing, management and psychology. It is important to understand consumer profile and behavior and to create personalized approach. A study conducted in 2002 by the Brazilian Environmental Ministry (Hoppe et al., 2013) identified that $73 \%$ of the Brazilian consumers show interest in purchasing organic products for consumption and that $81 \%$ seem to be motivated to buy it when the label informs that it was produced following the organic product's regulations and it is environmental friendly.

Consumer behavior is defined as the behavior that consumers project in searching for, using, purchasing, evaluating, and disposing of products and services that they assume will satisfy 
their needs (Nicolae, Pelau, 2011). Researching consumer behavior studies the manners in which consumers actually use the products and services they buy how many different brands they use, how often and where they make purchases and why they buy and use them and what they buy. The factors that affect consumer behavior can be divided into two major groups: external and internal factors. External factors include demographic, sociological, economic and geographical factors. Internal factors consist of the characteristics of personality as are features and mental conditions. They are strongly influenced by external factors and affect the formation of attitudes, opinions, teachings and motives of consumers (Novaković-Rajčić, 2005). The analysis of factors shaping consumers profile and affecting consumer behavior is a very complex process and of great significance to every marketoriented company for it's positioning at the market (Vladisavljević, 2016).

There is a growing interest in consumer behavior, not only in the field of marketing but from the social sciences in general. Spread of consumer culture via marketing is not always well received by social critics and consumers. Consumption can be regarded as playing such an important role in social, psychological, economic, political and cultural lives and it has become the 'vanguard of history' (Solomon et al., 2006).

Motivated by this expressive growth of the organic market, several studies concerning consumer behavior towards organic food have been conducted in many countries (Baker et al., 2004, Willer, Klicher, 2009), Such studies contain a focus of analysis whose emphasis is given to the values, motivations and beliefs of this consumer. Most of them have investigated how consumers perceive organic products and what are consumers' attitudes towards them. In general, the studies conducted in Europe revealed that purchase intentions of organic foods were linked to health and environmental consciousness but also to safety and quality issues.

Economic theory has shown some limits related to the assumption of consumer rationality. Most economic models use prices and income as explanatory facts of consumer behavior. They treat all other influences such as social, economic and cultural factor as intangible variables (Zanoli, Naspetti, 2002).

A consumer profile is describing consumers so that they can be grouped and segmented for marketing and advertising purposes. They are base for targeted advertising and creation of specific market segments what makes marketers more successful in selling and increase profits. By defining the ideal customer, patterns should be noticed that may be useful in target advertising.

Consumers could be represented by categorical tiers. The first tier is describing consumers with their demographics, socioeconomic status, and product usage. The second tier includes psychographics. Basic definitions of these concepts are provided below:

- Demographic: Attributes related to age, location of residence, gender, ethnicity, and type of household.

- Socioeconomic: Attributes related to educational level, household income, occupation, neighborhood, and memberships to any social groups. 
- Brand affinity/Product usage: Attributes associated on the basis of their behavior.

- Psychographics: Attributes related to lifestyles, personality, attitudes, life stage and opinion (DeVault, 2016).

Some authors have performed socio-demographic analyses for two or more countries. Parallel research in Germany and Turkey indicates that, organic consumers are from the different age groups. Gender behavior is different, females are dominant in Germany, on the other side Turkey has succeeded in reaching also the male in the market. Household structures are different, German organic consumers are generally singles or couples. In Turkey households particularly consist of 4 and more members. Similarities between two nations are that generally organic consumers have high education levels, a full-time job and belonging to middle income groups (Mutlu, 2007). In a study made in Turkey, most user of organic food was male, 36-45 years, university graduate and, married. They prefer to buy milk that is type or organic product. Four factors are important for consumer to motivate buying organic foods. These are healthy, quality, price and food safety (Ozguven, 2012).

As the main obstacles for the use of organic food in Chez Republic, there are marked insufficiently developed distribution channels and low awareness of the consumers about high quality organic products. The consequence is that low consumers' interest does not motivate the dealers to enlargement of the offer of the organic products (Živělová, 2005).

Socio-demographic characteristics may also influence consumer choices on organic food consumption. According to Stolz et al. (2011), higher income is significantly related to a consumer's preference to purchase organic foods and conventional plus (product categorized as 'in between' organic and conventional products, or food products with particular attributes that also apply to organic products). Gracia and Magistris (2008) indicated that income has an impact on organic food choice in the south of Italy, as lower-income consumers are less likely to buy organic foods. Meanwhile, females with children under 18 years of age, and small household size, are indicated as a significant factor in explaining consumer choices on organic product (Loureiro et al., 2001).

The aim of authors is to determine the socio-demographic profile of organic food consumers in Serbia. Such data are significant for creating marketing strategies and programs for the state administration in spreading organic food market and creating financial subsidies, as well as for all organic food producers in Serbia. They are essential as well for all other producers who have interest to distribute their organic food products on the market of Serbia. In addition, information is important for planning demand for organic food in short-term and long-term term for the market of Serbia. This gives weighty data for investments of producers and can give additional attic towards increase users of organic food products.

Authors performed research in which they wanted to confirm the following hypothesis:

\section{H1) Profile of organic food consumers is dependent on their socio-demographic characteristics.}

H2) An universal organic food consumer profile should be shaped. 
The profile would consist of the following group of characteristics:

H2.1) Demographic features:
a) age
b) gender
c) education
d) urban of rural place of leaving

H2.2) Sociological characteristics:
a) family size
b) income
c) who do they buy for
d) where do they buy
e) what are reasons to buy
f) what are obstacles for buying

H2.3) Human habits:
a) kind of products they use
b) frequency of buying
c) preparedness to pay more
d) positioning of nutrition value
e) healthy eating habits
H2.4) Human psychology:

a) impact of opinions of others on the purchase of organic food.

\section{Material and methods}

In researching consumer performances authors applied the quantitative research method. This enables to carry out statistical analysis which results can be generalized onto broader population. The survey method was applied. A questionnaire was used for conducting the survey created for the purpose of this research. A randomly selected sample of consumers in Serbia was tested. Data collection was done through phone calls and via e-mail.

The major socio-demographic characteristics of a sample of organic food consumers are then differentiated. A questionnaire was elaborated specifically for this proposes and contains 17 questions grouped in 6 groups:

1) Basic data: age, gender, level of education, number of family members, level of income per month per his household, country of living, place of living: urban or rural.

2) Reason: 
What is reason to purchase, whose impact is to purchase, for whom they are buying

3) What and where:

Description on what, where and how often and what product are they buying.

4) Opinion: Nutrition level excepted from buyers.

5) Obstacles to buy: high price, no enough distribution places, poor habit, lack of products and similar.

6) Willingness to pay more for organic food

7) Influence of other people concerning decision to buy organic food.

Activities of research were as follows:

- $\quad$ selection of testing sample

- $\quad$ elaboration of an appropriate questionnaire

- $\quad$ testing sample by questionnaire

- $\quad$ using the results of analysis, and identification appropriate marketing approach.

The research sample consisted of 398 randomly selected respondents. Authors used method of random selection a representative sample. The data were analyzed using SPSS for Windows 20. The methods which were used are: descriptive statistics - frequencies and percentages and geographic presentation.

\section{Results and discussion}

The research was performed during two phases of analysis.

1. Authors analyze gender, age structure, education level, household size and income value as the most important demographic characteristics of consumers (independent variables) in relation with their choice for organic food usage, as the first phase of research.

2. In the second phase they analyzed which facts are important in consumer behavior during purchases by studying (dependent variables):

- Where do they most often buy organic products

- What do they buy the most

- What is reason to buy

- What are barriers to decide to purchase

- Whose influence is on purchasing

From 398 examinees, based on the data presented in the Figure 1, we have noticed that $78.1 \%$ (311) respondents use organic products in their nutrition what forms a significant percentage. This is almost 4 times more than those who do not consume organic food. Such result is similar to results of research done in USA which has shown that are about three quarters (73 percent) of U.S. adult consumers, as given in Hartman group report (Hartman Group, 2014). 
Figure 1. Do you utilize organic products in your nutrition?

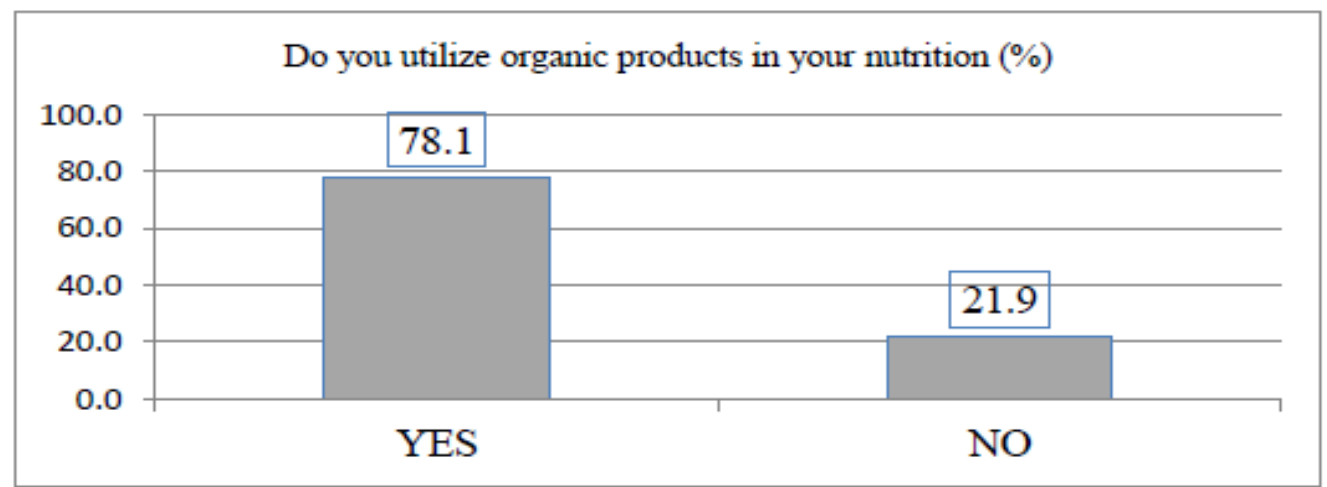

Source: Authors calculation based on collected data

The data presented in the Figure 2 indicate that the highest percentage of consumers is from urban surroundings, almost 6 times more than from villages. This is in line with results of the study about Czech Republic which concluded that organic food is more likely purchased by younger households from larger cities (Zvěřinová et al., 2011).

Figure 2. Place of living

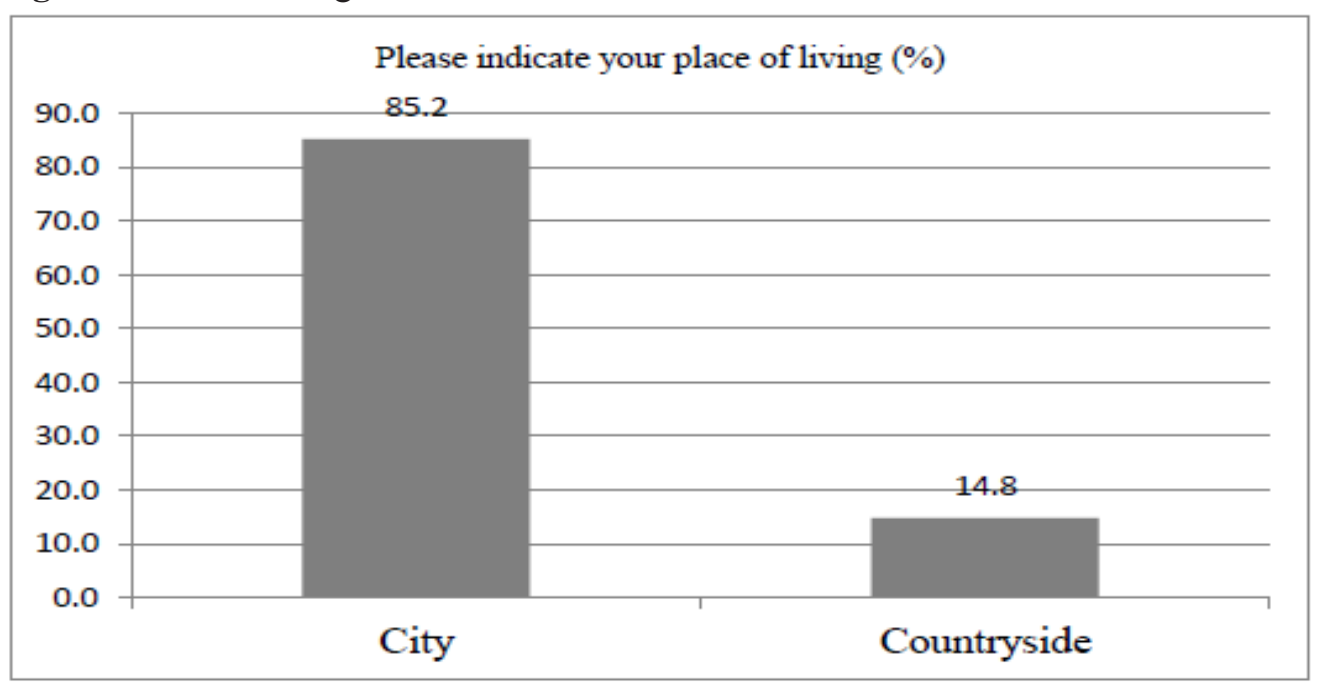

Source: Authors calculation based on collected data

In the Figure 3 is shown that the most consumers are of the age between 31 and 40, 33.8\% and the least are of the age up to 20 and over 60 . Actually, aged population is consuming less organic products than younger despite they are actually more prone to the health problems. Young generation adopts new products easier and is more under media influences. The situation in USA is slightly different, the average age of organic food consumers 41.5 years (Hartman Group, 2014). 
Figure 3. Age of organic food consumers

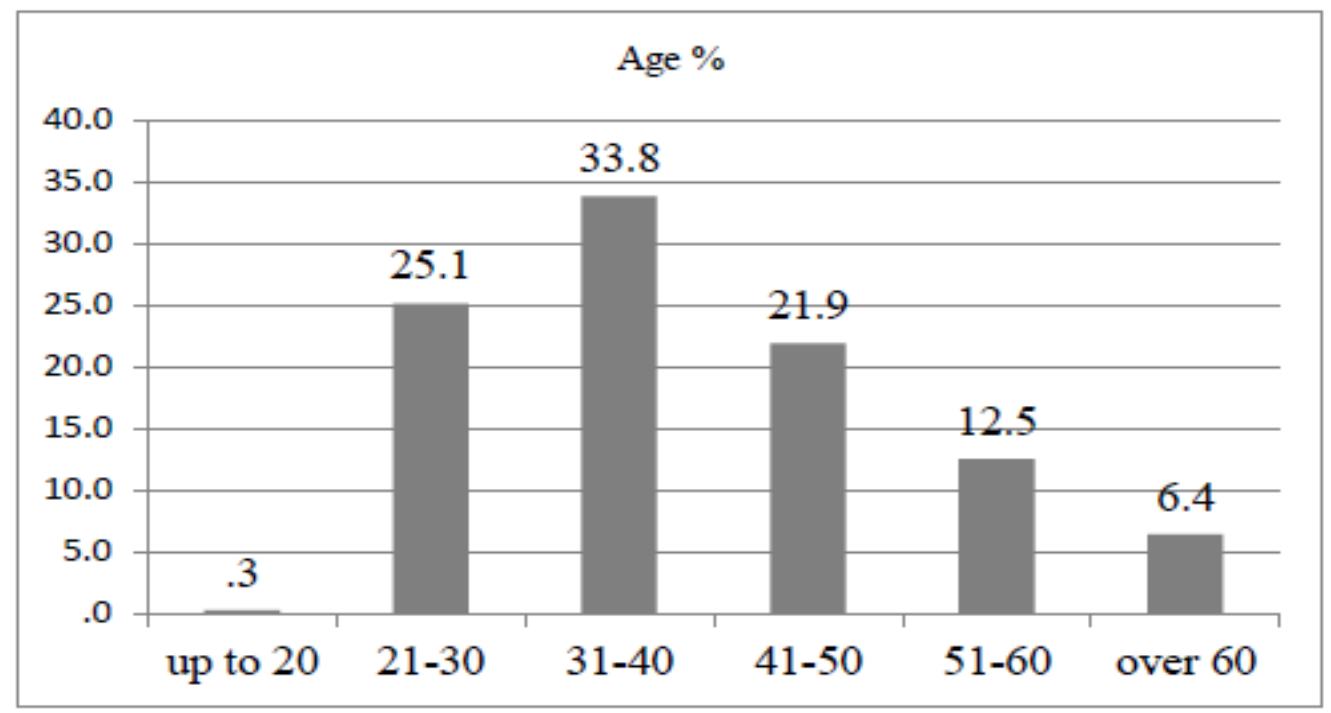

Source: Authors calculation based on collected data

In case of tested sample female are more oriented towards healthy food. About $20 \%$ more female are purchasing organic what could be explained by caring more about their phyisical appearance, health status and easier spending of money (Figure 4). Similar findings is in research of Loureiro and al (2001). Further research could include different groups of female with their subprofils.

Figure 4. Gender of organic food consumers

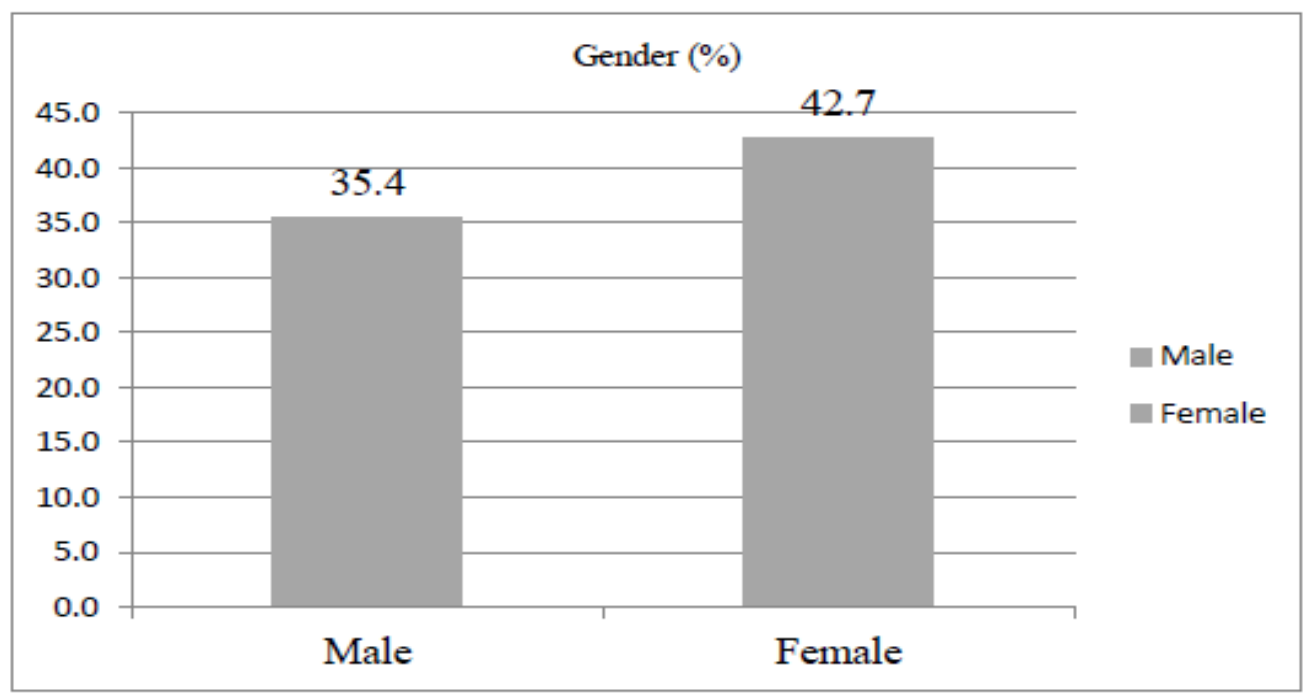

Source: Authors calculation based on collected data 
The figure 5 presents the dependence of organic food consumers on the level of their education. It can be seen that as higher education people have, the more they are using organic nutrition. Within the example of Serbia, organic food users have university degree, $57.2 \%$ and $24.8 \%$ of people have master degree, that is $82 \%$ of all. Education is bringing knowledge and awareness about change of habbits and turning towards better choice. The Organic \& Natural 2014 report of The Hartman Group presents that 50\% organic users are College graduate or with higher education in USA (Hartman Group, 2014). In Serbia the segmentation is even stronger, there are no consumers with lower education than high school, and $82 \%$ are graduate consumers.

Our finding is not correlated with some research which states that education and income, in spite of having, on average, a better discriminating power, in some situations are shown to be weak segmentation criteria (Marreirosi et al., 2010). This result is in line with some authors' opinion (Solomon et al., 2006) that in modern societies differences in consumer behaviour are better explained by constructs such as values and life-styles than by the traditional demographic criteria.

Figure 5. Education of organic food consumers

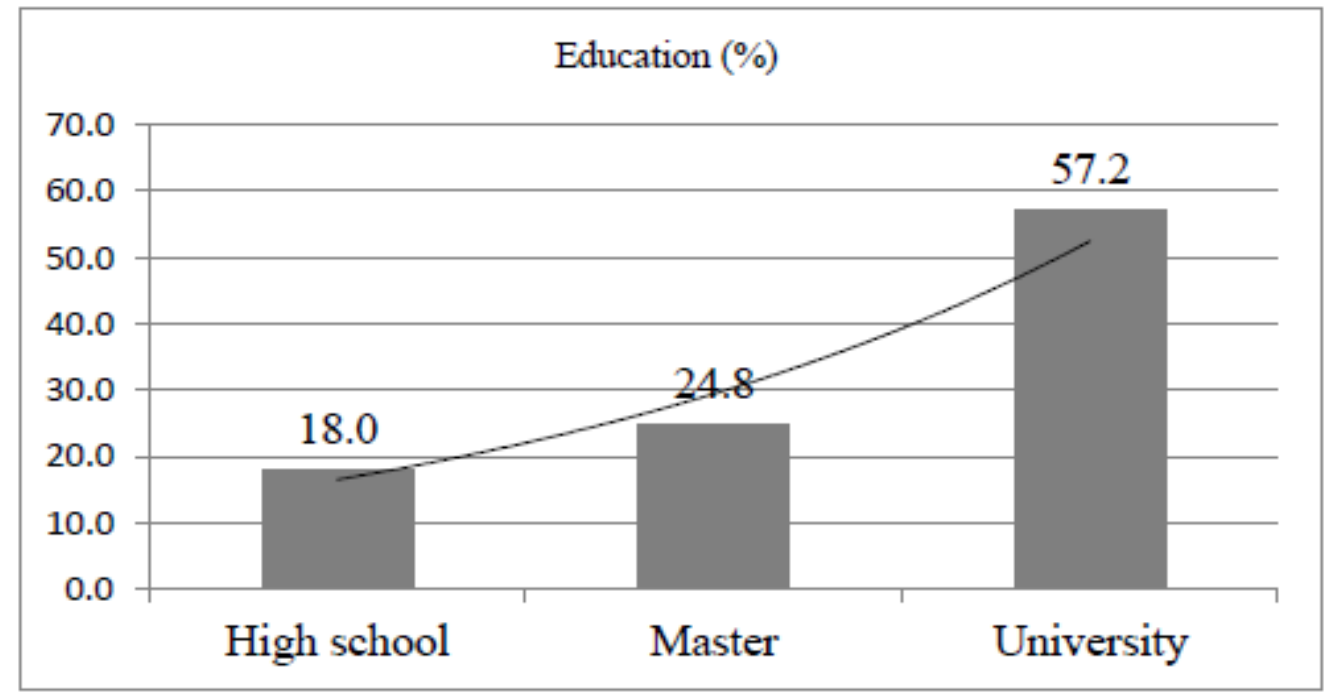

Source: Authors calculation based on collected data

The small housholds is indicated as houshold with up to 4 members and consumers in $89.4 \%$ belong to this groups, $10 \%$ to the group of avarage size houshold with 5 to 6 members and only $0.6 \%$ are members of big housholds with more than 6 members. Such distribution is consequence of economical situation within big families. 
Figure 6. Household size of organic food consumers

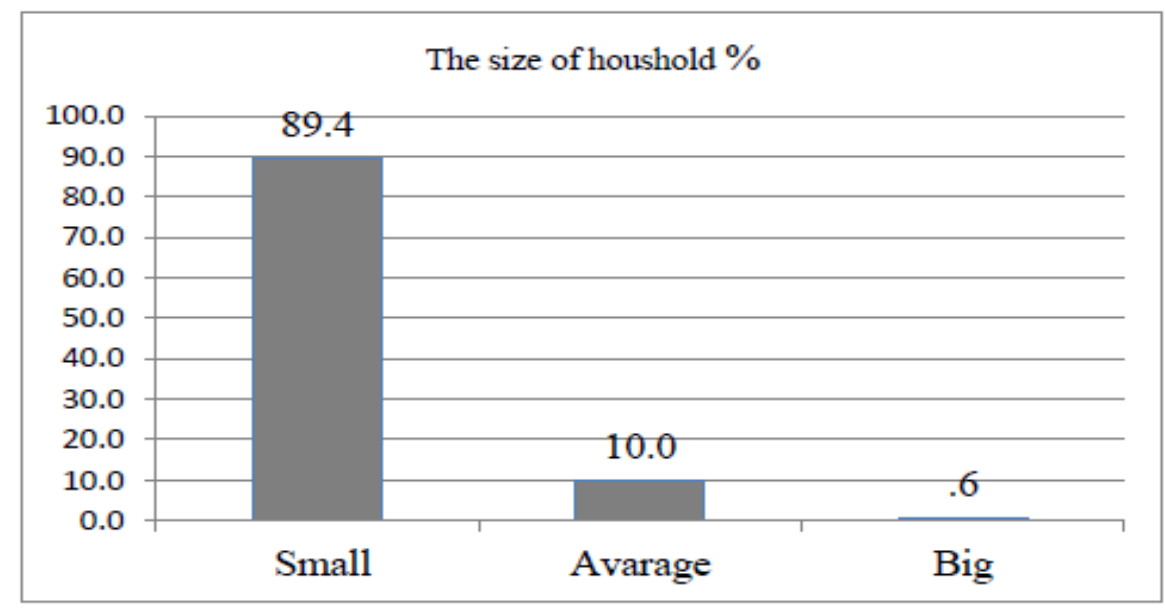

Source: Authors calculation based on collected data

What about relation between income and percentage of organic food consumers? As could be seen in Figure 7 most users have an income of 501 to 1000 eur. In Serbia is average wage is lower what indicates that higher earning people can afford organic food more and consume it more intensively.

Figure 7. Average income of organic food consumers

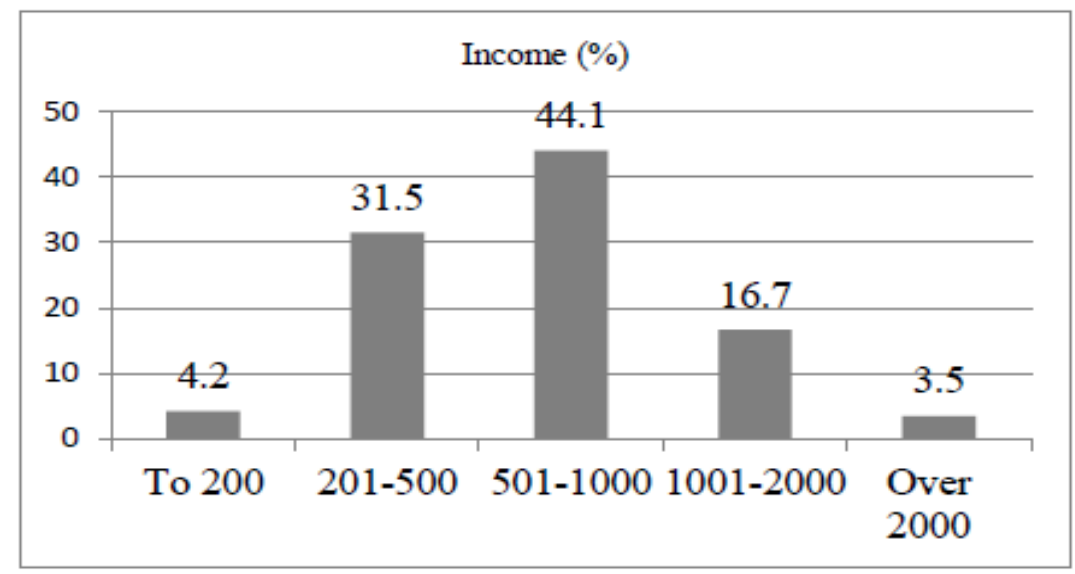

Source: Authors calculation based on collected data

The Hartman Group report (2014) states that while demographic differences are not at the heart of organic values and behaviors, there are nonetheless some differences in the demographic characteristics of consumers across the different segments. Organic users are more likely to have higher incomes and be more educated, younger, be employed full time. The findings are completely same as in author's research despite of big differences between countries.

Figure 8 presents that care about family is a main driver for buying organic food in $74.6 \%$ of 
respondents, than the consumers that buy it for themselves $(18.7 \%)$ which is consistent with findings of Kulikovski and Agolli (2010) of organic food consumption in Greece.

Figure 8. For whom the organic food is bought for

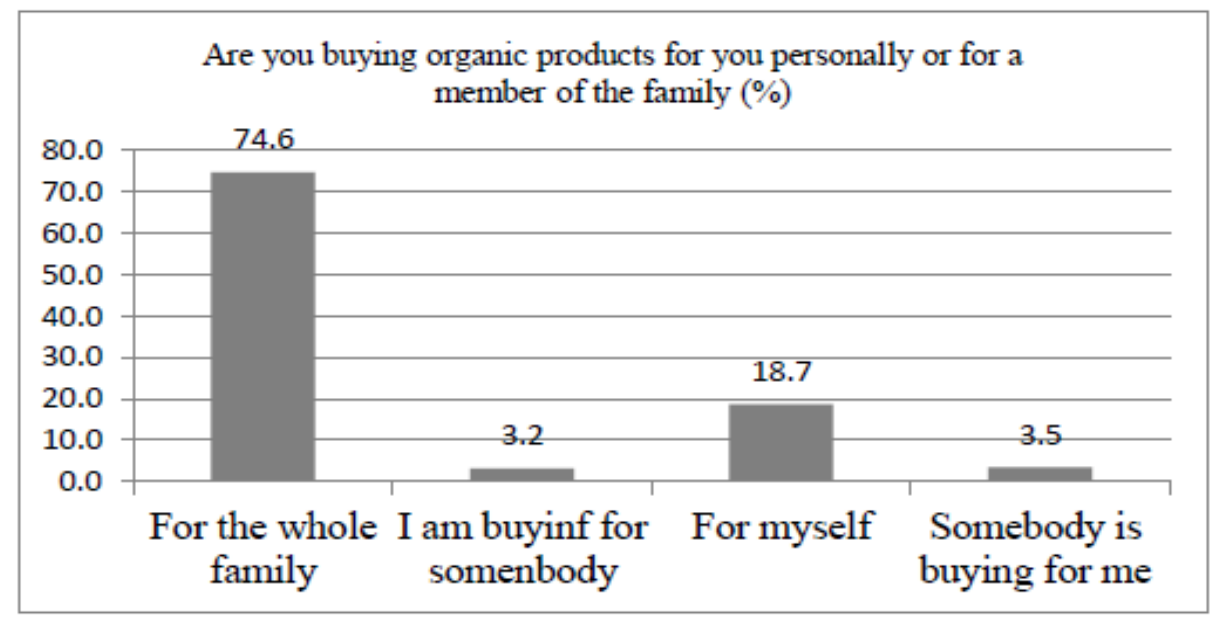

Source: Authors calculation based on collected data

What about willingness to pay more for organic food? The most consumers are ready to pay 10 to $20 \%$ more than for standard food. Big percentage of them would even like to pay 20 to $30 \%$ more. Some authors stated that there is a large share of consumers that are willing to pay more for organic products, but not willing to pay as much as the market price and are willing to pay even more, depending of the product type (Millock at al., 2002).

Figure 9. Willingness to pay more for organic food

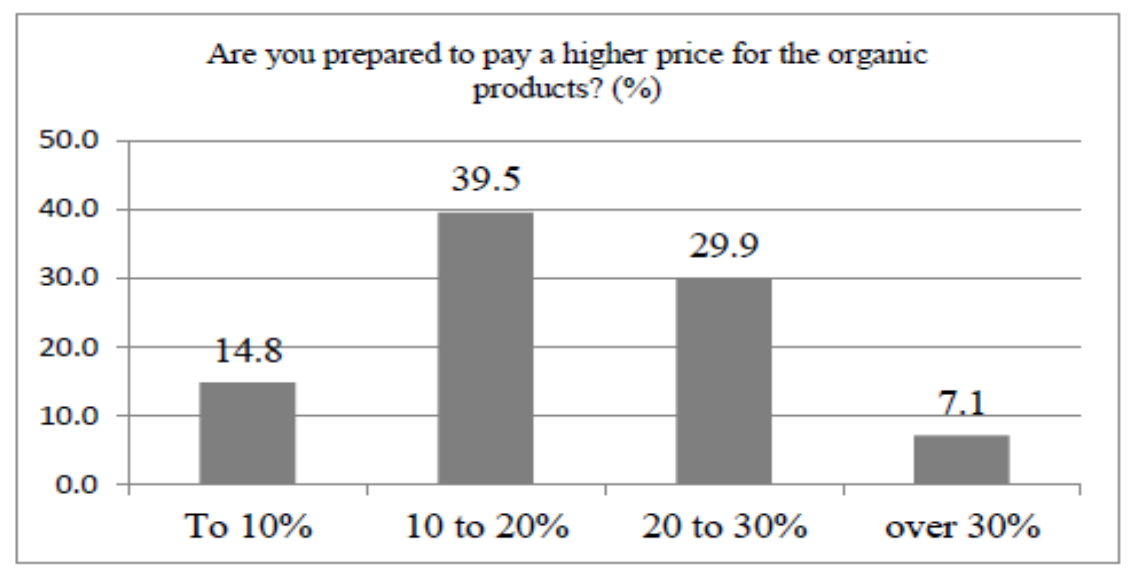

Source: Authors calculation based on collected data

When discussing frequency of buying, analysis shows that $79.8 \%$ are buying once or couple times a month for organic food. There is a significant percent $(12.9 \%)$ of consumers who are buying it every day which is in line with findings of Loureiro et al (2001). 
Figure 10. Frequency of buying organic food

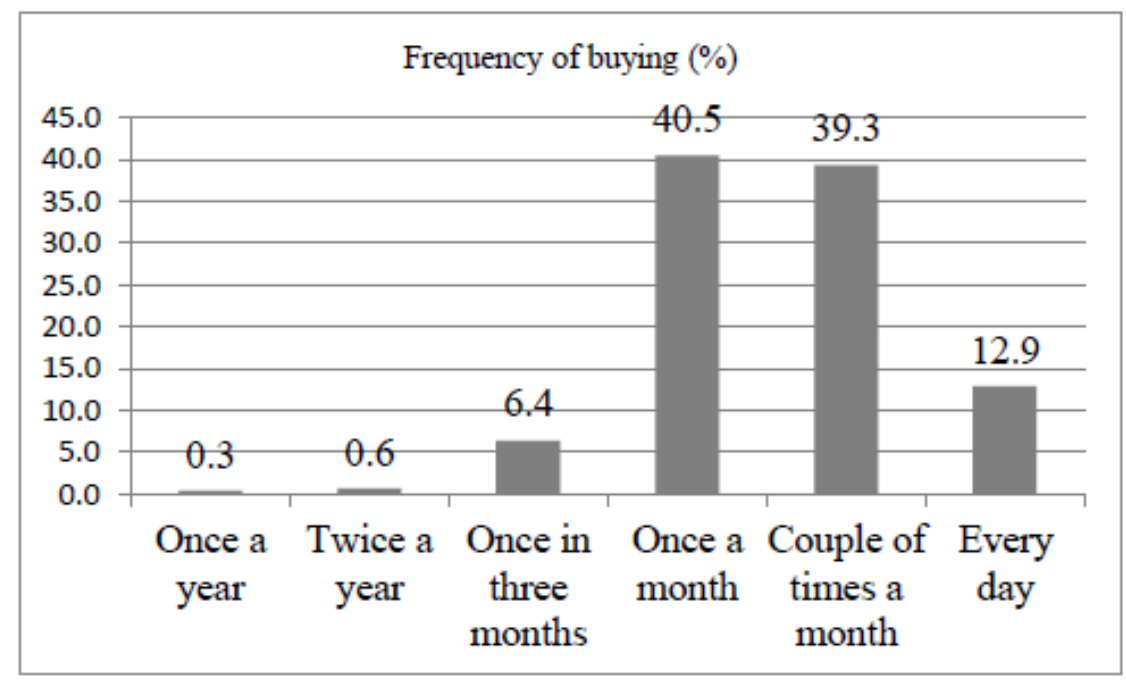

Source: Authors calculation based on collected data

From the Figure 11 it can be observed that $92.5 \%$ percent of examinees answered that they consider nutrition quality of organic food to be high, with marks 3 to $5,21.5 \%$ answered gave the highest mark for organic food nutrition quality.

Figure 11. How consumers evaluate nutrition level of organic food

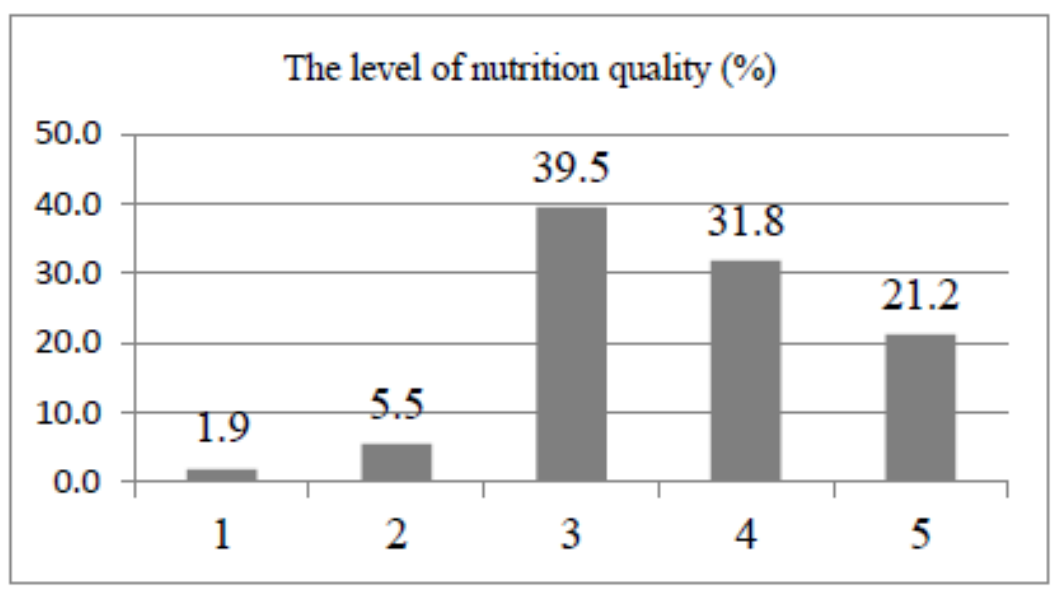

Source: Authors calculation based on collected data

Later in the research, authors analyzed how some factors have been reflected in consumer behavior during purchases by studying: what they buy, where they buy, what are reasons and what are barriers for purchasing and whose influence is dominant in the decision to buy (dependent variables).

Results of some questions with multiply choice are presented in tables and discussed, follow: 
Table 1. The type of organic product bought and place of buying

\begin{tabular}{|l|r|l|r|}
\hline $\begin{array}{l}\text { Which organic products do you } \\
\text { buy the most often? }\end{array}$ & Frequency & $\begin{array}{l}\text { Where do you buy organic food } \\
\text { the most? }\end{array}$ & Frequency \\
\hline Fresh vegetables & 225 & Market & 167 \\
\hline Fresh fruit & 220 & Big markets & 139 \\
\hline Cereal & 143 & Health food stores & 128 \\
\hline Milk and dairy products & 129 & From producers & 123 \\
\hline Dry fruit & 42 & Specialty shops & 46 \\
\hline Organic cotton clothes & 37 & & \\
\hline Meet & 4 & & \\
\hline Honey & 2 & & \\
\hline Nuts & 1 & & \\
\hline Flour & 1 & & \\
\hline Seeds & 1 & & \\
\hline Oil & 1 & & \\
\hline Total & 806 & Total & \\
\hline
\end{tabular}

Source: Authors calculation based on collected data

The most consumed are the organic fresh fruit and vegetables, and in the least nuts, flour, seeds and oil. The users like to buy organic food mostly in markets and in big markets-shopping centers and at least in specialty shops. From the answers, it can be seen that customers like to buy organic fruits and vegetables in the marketplaces. Therefore, it is recommended that small organic farmers should be selling their products in such marketplaces. This finding is in line with the view of Zámková and Blaškov (2013).

Table 2. Reasons for buying organic food

\begin{tabular}{|l|r|l|r|}
\hline $\begin{array}{l}\text { What is your reason for buying } \\
\text { organic food? }\end{array}$ & Frequency & $\begin{array}{l}\text { Do you have an impact on your } \\
\text { purchase of opinions of others? }\end{array}$ & Frequency \\
\hline Care for my health & 212 & I make my decision & 179 \\
\hline Health care for children & 126 & Medical doctors & 46 \\
\hline Better taste and quality & 113 & Family & 712 \\
\hline $\begin{array}{l}\text { They have less , chemistry“ } \\
\text { inside }\end{array}$ & 172 & Friends & 75 \\
\hline High environmental awareness & 40 & Media & 34 \\
\hline Due to animal welfare & 15 & & \\
\hline Out of curiosity & 17 & & \\
\hline Total & 695 & Total & \\
\hline
\end{tabular}

Source: Authors calculation based on collected data

EP 2017 (64) 2 (497-514) 
When discussing reasons for purchasing organic food, from the Table 2 it can be seen that customers decide to purchase them to protect their health in mostly cases and because they believe that such product contain less chemistry. Examinees have high awareness about personal health and much less towards environmental care and animal welfare (5.8 and 2.2\%).

Table 3. Obstacles for buying organic food

\begin{tabular}{|l|r|}
\hline Obstacles to the purchase of organic products & Frequency \\
\hline High price & 126 \\
\hline Not available sale sites & 75 \\
\hline I do not believe into the organic mark & 41 \\
\hline Insufficient developed distribution channels & 96 \\
\hline Poor offer & 87 \\
\hline I do not have enough knowledge and experience & 47 \\
\hline Continue in offer & 57 \\
\hline Quantity of offer & 31 \\
\hline I do not have formed habit & 51 \\
\hline Nothing of offered answers & 34 \\
\hline Less attractive look & 8 \\
\hline I do not see advantages comparing to traditional products & 4 \\
\hline Total & 657 \\
\hline
\end{tabular}

Source: Authors calculation based on collected data

As it can be seen in the Table 3 the problems that respondents have during process of buying products are high prices and insufficient developed distribution channels. Additionally, there is a poor offer with not a lot of available sale sites. The selling network must be improved and should recognize consumers' needs. The most users deciding on the purchase based to their own decision, and then under influence of family members. This brings us to the conclusion that decisions about type of food consumption are very personal.

Based on a survey of customers on the territory of Serbia, the customer segment has been analyzed and derived from this research. It is proved that customers who are willing to purchase have a typical, universal customer profile with following demographic, economic, sociological and geographical characteristics: According to the gender structure of customers women consumers are statistically significant. By age, the customers who are dominant in the purchase of organic food are persons from 31 to 40 years. According to the education level, the purchase of organic food is dominated by people with university degrees. According to the number of members in the household the small, three-four-member households dominate.

Due to the overall average household income in the purchase of organic food are dominated by households with an income of 501 to 1000 euro per month. Buyers of organic food are people who say they use partially healthy food. So these are people who have a distinguished tendency towards a healthy lifestyle. They prefer buying for the whole family, mostly fresh fruit and vegetables at markets, directly from producers and then from the health food shops. 
Consumer trust is higher in local farmers than shopping centers and this requests direct marketing from local supplier to consumer.

The motives for the purchase of organic food are that it is healthy and with less chemistry. The most users are buying once or couple times a month and are willing to pay mostly 10 to $20 \%$ more that for standard food. The obstacles they are confronting with are high price and underdeveloped supply chain. The nutrition value which they accept is average, scored with 3. Decisions to enter new market segment of organic food are made very personally, under their selves' decisions and under influence of family only.

\section{Conclusion}

Based on a survey of customers on the territory of Serbia, authors confirmed set hypothesis that: profile of organic food consumers is dependent on their sociodemographic characteristics and according to the second hypothesis they shaped an universal organic food consumer profile for the territory of Serbia which should be in focus during marketing activities. The decision to buy is decision of buyers, there is non external influence. This requests a complex personalized approach to consumers, very personal. The doctors, nutritionists, psychologists should be part of marketers' strategies. On the other side other categories of people should be differently treated to become more intensive organic food consumers, mostly by raising awareness and trust. The social networks and social organic food marketing should be developed.

The authors suggest that marketers should use the study findings to develop specific strategies for the positioning, communication, pricing and distribution of organic food products. Defined consumers profile affects the promotion in order to improve sales, in order to increase the consumption of products and ultimately bring higher production. Increased consumption would be a stimulus for the organic production which protects environment and indirectly improves the health of people and reduces health system costs. The study is acknowledged as exploratory and a useful foundation for further research that should be extended to other provinces to find broader dependences and specifics.

\section{Literature}

1. Baker, S., Thompson, K.E.., Engelken, J.E., Huntley, K. (2004): Mapping the values driving organic food choice: Germany vs the UK. European Journal of Marketing, Vol. 38, No. 8, pp. 995-1012.

2. DeVault, G. (2016): Consumer Profile: Defining the Ideal Customer. Available at: https://www.thebalance.com/consumer-profile-defining-the-ideal-customer-2296932 (accessed: 15 January 2017)

3. DG Agriculture and Rural Development, Unit Economic Analysis of EU Agriculture (2016): Facts and figures on organic agriculture in the European Union. Available at: http:// ec.europa.eu/agriculture/rica/publications_en.cfm, European Union. (Accessed: January 2017)

4. Gracia, A, De Magistris, T. (2008):The demand for organic foods in the South of Italy: A discrete choice model. Food Policy, 33, pp. 386-396.

EP 2017 (64) 2 (497-514) 
5. Hartman Group (2014): Organic \& Natural 2014 report, available at: http://store. hartman-group.com/content/organic-and-natural-2014-overview.pdf (accessed: 26 January 2016)

6. Heinye. K. (2016): European organic market grew to more than 26 billion euros in 2014, http://organic-market.info/news-in-brief-and-reports-article/european-organic-marketgrew-to-more-than-26-billion-euros-in-2014.html(accessed: 26 January 2016)

7. Hoppe, A., Vieira, L., Barcellos, M. (2013): Consumer behaviour towards organic food in porto alegre: an application of the theory of planned behavior. Rev. Econ. Sociol. Rural Vol. 51, No.1, pp. 123-134.

8. Hughner, R., McDonagh, P., Prothero, A., Shultz, C., Stanton, J. (2007): Who are organic food consumers?. A compilation and review why some people purchase organic food, Journal on Consumer Behaviour, Vol.6, No.2-3, pp.94-110.

9. Kulikovski, V., Agolli, M. (2010): Drivers of organic food consumption in Greece, School of Economics and Business Administration, Thessaloniki.

10. Loureiro, M.L., McCluskey, J.J., Mittelhammer, R.C. (2001): Assessing Consumer Preferences for Organic, Eco-labeled, and Regular Apples. Journal of Agricultural and Resource Economics, Vol. 26, No. 2, pp.404-416.

11. Marreirosi, C., Lucas, MR., Röhrich, K. (2010): Explaining organic food choice on the basis of socio-demographics. A study in Portugal and Germany, CEFAGE-UE Working Paper, 2010/3, Universidade de Évora, Portugal.

12. Millock, K., Hansen, L.G., Wier, M., Andersen, L.M. (2002): Willingness to pay for organic foods: a comparison between survey data and panel data from Denmark, Proceedings of the Conference on Consumer Demand for Organic Foods, Denmark, available at: http:// econweb.ucsd.edu/ carsonvs/papers/5065.pdf (accessed 15 April 2017).

13. Mutlu, N. (2007): Consumer attitude and behavior towards organic food: Crosscultural study of Turkey and Germany, Master Thesis, University Hohenheim, Stuttgart.

14. Nicolae, I, Pelau, C. (2011): Consumer behavior on the fruits and vegetables market. Annals of Faculty of Economics, Vol. 1, No. 2, pp.749-754.

15. Novaković-Rajačić, B. (2005): Ponašanje potrošača, Evropski univerzitet, Beograd. 16. Ozguven, N. (2012): Organic foods motivations factors for consumers. Procedia Social and Behavioral Sciences 62, pp. 661-665.

17. Shepherd, R., Magnusson, M., Sjödén, P. (2005): Determinants of Consumer Behavior Related to Organic Foods, Ambio, Vol. 34, No. 4/5, pp. 352-359.

18. Simeunović, T. (2016): Menadžerski aspekti međuzavisnosti zaštite životne sredine i budžeta, Oditor, Vol. 2, No. 1, pp. 25-30.

19. Solomon, M., Bamossy, G., Askegaard, S., and Hogg, M. (2006): Consumer Behaviour A European Perspective, Prentice Hall Europe, ISBN10: 0-273-68752-2

20. Stolz, H., Stolze, M., Janssen, M., Hamm, U. (2011): Preferences and determinants for organic, conventional and conventional-plus products-The case of occasional organic consumers. Food Quality Preference, Vol. 22, pp. 772-779.

21. Vapa-Tankosić, J., Stojsavljević, M. (2014): EU Common Agricultural Policy and Pre-Accession Assistance Measures for Rural Development. Economics of Agriculture, Vol. 
61, No. 1, pp. 195-2010, UDC: 005.51:631EU, ISSN 0352-3462

22. Vladisavljević, V. (2016): Novi sistem udruživanja Corner Shop-ova u Srbiji, Oditor, Belgrade, Serbia, Vol. 2, No. 2, pp. 35-49.

23. What does organic mean? (2016): Available at: http://www.organic.org/home/faq (accessed: February 2016)

24. Willer, H. E., Klicher, L. (2009): The world of organic agriculture: Statistics and emerging trends, Bonn: IFOAM \& FiBL, p.24. Available at: www.organic-world.net (accessed: January 2016)

25. Zámková, M., Blaškov, V.(2013): The differences in the marketability of organic products in Greece and the Czech Republic, Agricultural Economics, Vol. 59, No. 5, pp. 219-226

26. Zanoli, R., Naspetti, S. (2002): Consumer motivations in the purchase of organic food. A means-end approach. British Food Journal, Vol. 104, No. 8, pp. 643-653, DO I 10.1108/000707002104259

27. Živělová, I. (2005): Current situation of demand for organic products in the Czech Republic. Agricultural economics, Vol. 51, No. 7, pp. 304-308

28. Zvěřinová, I., Urban, J., Ščasný, M. (2011): Why do Czech consumers purchase organic food?, 3th scientific Conference New findings in organic farming research and their possible use for Central and Eastern Europe, Prague. 


\title{
PROFIL POTROŠAČA ORGANSKE HRANE
}

\section{Mirjana Kranjac ${ }^{4}$, Jelena Vapa-Tankosić5 ${ }^{5}$ Milena Kneževićc}

\begin{abstract}
Apstrakt
Cilj ove studije je da se dokaže da profil organskih potrošača hrane zavisi od njihove sociodemografskih karakteristika kao i da oblikuje univerzalni profil potrošača organske hrane. Istraživanje je bilo obuhvaćeno 398 potrošača u Srbiji. Podaci prikupljeni su analizirani pomoću softvera SPSS 16. Rezultati ukazuju na postojanje profila tipičnih potrošača. Rezultat ukazuju da je sociodemografski profil kod većinskog stanovništva povezan sa odlukom o korišćenju organske hrane. Ovaj rad doprinosi svim zainteresovanim učesnicima, jer poznavanje odlika organskih potrošača može doprineti njihovoj aktivnijoj ulozi u ovom lancu snabdevanja. To bi trebalo da podstakne personalizovanu pristup izrađen na osnovu socio-demografskih karakteristika i usmeren ka određenim grupama potrošača u cilju intenziviranja potrošnje organske hrane i stvaranja različitih marketinških planova zavisno od pojedinih zemalja ili područja.
\end{abstract}

Ključne reči: organska hrana, profil potrošača, socio-demografske karakteristike, lanac snabdevanja.

4 Vanredni profesor, dr Mirjana Kranjac, Univerzitet u Novom Sadu, Novi Sad, Fakultet tehničkih nauka, Trg Dositeja Obradovića br. 6, 21000 Novi Sad, Srbija, Telefon: +381 62633 590, E-mail: mirjana.kranjac@uns.ac.rs.

5 Vanredni profesor, dr Jelena Vapa-Tankosić, Univerzitet Privredna akademija, Cvećarska ulica br. 2, 21000 Novi Sad, Srbija, Telefon: +381 63460 585, E-mail: jelena.vapa@fimek.edu.rs

6 Dr Milena Knežević, Univerzitet odbrane u Beogradu, Pavla Jurišića Šturma br. 1, 11000Beograd, Srbija, E-mail: milena.knezevic@mod.gov.rs 